Agnes Imhof

\title{
Traditio vel Aemulatio? \\ The Singing Contest of Sāmarrā', Expression of a Medieval Culture of Competition
}

Abstract: There is hardly any evidence suggesting that the singing contest of Sāmarrā' deals with traditio. Music is mainly performance, and the significance of improvisation allows the singer, male or female, to assume a key position. Regardless of the school, Arab Music of the 9th century is characterized by the aemulative event, especially in the form of competition and contest.

Keywords: singing contest, singing slaves, Sāmarrā', court culture.

Agnes Imhof: München, agnesimhof@web.de

The rivalry between two famous female singers was the topic of the day in alMutawakkil's (r. 847-61) Sāmarrā', according to the Kitāb al-aghānī. We are told that ${ }^{1}$ "the refined and well-bred people at this time were divided into two communities, one of them supporting 'Arīb ('Arībiyya), the other one backing Shāriya (Shärawiyya) ...” Further, in the same context:2 "(...) The supporters of one party did not use to visit those of the other one, nor were they friends with each other."

The texts are concerned with the most famous female singers of their time. Their rivalry was interpreted by J.E. BENCHEIKH ${ }^{3}$ as a mere continuation of a querelle des anciens et des modernes between two musical "schools," whose actual exponents had been the singers Ishāq al-Mawșilī (d. ca. 850) and Ibrāhīm ibn al-Mahdī (d. 839). In fact, Isḥāq al-Mawșilī is usually regarded as an exponent of the classical Arabic musical tradition from the Hijāz, to which 'Arīb may have also been inclined. As opposed to this, Shāriya's teacher, the 'Abbāsid prince Ibrāhīm

1 13, p. 29. Abū l-Faraj al-Ișfahānī, Kitāb al-Aghānī, Dār al-Fikr, 21 parts and Index in 9 vols. equivalent to the edition Kairo 1322/1905-5. Quoted below "Agh" the first number referring to the respective part.

2 14, 109.

3 Les musiciens et la poésie. Les écoles d' Isḥāq al-Mawșilì (m. $225 \mathrm{H}$ ) et d'Ibrāhīm ibn al-Mahdī (m. 224 H), in: Arabica 22 (1979), fasc. 2, 114-152, especially 146f. 
ibn al-Mahdi, preferred the modernist Persian style, which was characterized inter alia by redundant improvisation. ${ }^{4}$ Consequently, traditio in our context refers to these musical traditions, and in a broader sense, to a concept close to Latin imitatio or Greek $\mu$ í $\mu$ бı - consulting an (elder) paragon with the aim of converging 5 or transmitting it.

Aemulatio, on the other hand, is defined as "competing with a stylistic or poetical paragon, in order to outreach and even surpass it." 6 Originally a rhetorical concept, the notion of aemulatio has been adopted by other disciplines, such as literary criticism and art history. Aemulatio requires knowledge of the paragon, i.e., of the (musical) tradition.

We will discuss the question of whether or not the rivalry of the female singers is to be regarded as a querelle, a quarrel, between two traditiones. Are they mere representatives and thus imitating elder paragons, with the rivalry between them being, in fact, one between two schools? Or is their contest a personal one as would be suggested by interpreting it as aemulatio - and thus indicating individualization?7

\section{The sources and the singers}

Several works from the elder scientific literature have adopted the polemics of Islamic theologians almost uncritically: singing-girls as a phenomenon of deca-

4 As I will discuss below these terms, these, especially "romanticism" for the Persian style, are problematic. In the absence of a better alternative, I will thence refer to them as classical Arabic and modernist Persian style. However, we still lack a comprehensive analysis of both musical traditions. For a general survey, see Amnon SHILOAH, Music in the World of Islam. A Socio-Cultural Study, Aldershot 1995 and IDEM: The Theory of Music in Arabic Writings (c. 900-1900), 2 vols., Henle: München 1979, 2003. Still useful is the work of Hans HickMANN and Wilhelm STANDER, Orientalische Musik, in: B. SPULER (ed.) Handbuch der Orientalistik 1. Abteilung, Ergänzungsband 4, Leiden, Köln 1970, 1-134.

5 Like Byzantine monks, who were expected to imitate angels through their lifestyle. For a nuanced discussion of the notion, see Andreas RHOBY and Elisabeth SCHIFFER, eds., Imitatio Aemulatio - Variatio. Akten des internationalen wissenschaftlichen Symposions zur byzantinischen Sprache und Literatur (Wien 22.-25. Oktober 2008), Verlag der österreichischen Akademie der Wissenschaften: Wien 2010, 17-21, and F. Neumann, Tradition, in: Gert Ueding (ed.), Historisches Wörterbuch der Rhetorik, vol. 9, Tübingen 2009, 732-41.

6 Barbara BAUER, “Aemulatio”, in: Gert Ueding, Wörterbuch, vol. 1 (1992), 141-188.

7 Joel Kraemer, Humanism in the Renaissance of Islam, Leiden 1992, XXVI, 1ff, 11ff (on the 10th century) mentions individualism as a feature of a "Renaissance." 
dence. ${ }^{8}$ Later publications, such as those by Michael StigelbaUer (1975) ${ }^{9}$, Hans ENGEL (1987) ${ }^{10}$, George SAWA (1989/2004)11 or Abdul-Kareem AL-HeITTY (2005)12 provide us with a large amount of material, and yet, understandably, could not analyze the singing-girls' position exhaustively. Certainly, the most important biographical source for the life of the singing-girls is the Kitāb al-Aghānī. ${ }^{13}$ From numerous other sources, I will concentrate on the Risālat al-qiyān by al-Jāhị... ${ }^{14}$

'Arīb was probably born about 797 C.E., an alleged daughter of the Barmakid vizier Ja'far. She is said to be sold by her Christian nanny after the fall of the Barmakids in 803. This was how she came to 'Abdallāh Ismā'īl al-Marākibī, probably the caliph's equerry. Caliph al-Amīn cheated al-Marākibī out of his beautiful slave-girl: he invited the equerry to bring 'Arīb into the palace, so that authorities could examine her talent - and then kept her with him, making her his concubine. ${ }^{15}$ After 813, the new caliph al-Ma'mūn forced al-Marākibī to sell the singer to him. Al-Ma'mūn was so devoted to 'Arīb that she was called al-Ma'mūniyya. Still, she obviously did not return his affection - 'Arīb ran away from his palace to stay with her lover, got pregnant, and succeeded in being married to him. ${ }^{16}$

During the reign of al-Mu'tașim 'Arīb was manumitted - and took part in a hazardous political intrigue. When 'Abbās, al-Ma'mūn's son, planned a coup against his uncle al-Mu'tașim and his heir apparent, al-Wāthiq, she offered to kill

8 Like Alfred v. Kremer, Kulturgeschichte des Orients unter den Chalifen, Wien 1877, 111. More objective works from prior secondary literature are Charles PeLLAT, Kayna, in: EI vol. 4, 1978, 820-824, Henry G. FARMER, A History of Arabian Music to the XIII. Century, London 1929. IDEM, The Minstrels of the Golden Age of Islam, in: Islamic Culture XVII (1943), 273-281 and XVIII (1944), 53-61. 9 Michael Stigelbauer, Die Sängerinnen am Abbasidenhof um die Zeit des Kalifen al-Mutawakkil. Nach dem Kitāb al-Aḡānī des Abu l-Fară̆ al-Ișbahānī (sic) und anderen Quellen dargestellt, Wien 1975.

10 Hans Engel, Die Stellung des Musikers im arabisch-islamischen Raum, Bonn 1987.

11 George Sawa, Music Performance Practice in the Early Abbasid Era, Ottawa 2004 ('Toronto, Ontario 1989). SAWA points out similar competitions among singers (178ff), he also briefly quotes our singing contest (without referring to BENCHEIKH).

12 Abdul-Kareem AL-Heitty, The Role of the Poetess at the Abbasid Court (132-247 / 750-861). A Critical Study of the Contribution to Literature of Free Women and Slave-Girls under the Early Abbāsid (sic) Caliphate, their Biographies and Surviving Works, Beirut 2005.

13 For extensive biographies that are contradictory in details, see STIGELBAUER, Sängerinnen 18ff, and Al-HeitTy, Poetess (only 'Arīb, 73ff). Especially Stigelbauer, Sängerinnen, 7ff and AL-Heitty, Poetess, 350ff, give also bibliographies. AL-HeItTy lists lost sources as well.

14 A.F.L. BEESTON, The Epistle on Singing-girls of Jāhiz. Edited with Translation and Commentary by A.F.L. BEESTON, Guildford 1980. Quotations refer to this edition.

15 See Stigelbauer, Sängerinnen, 24.

16 See Stigelbauer, Sängerinnen, $152 \mathrm{ff}$. 
the latter personally. ${ }^{17}$ The conspiracy was detected, the conspirators were killed - except for 'Arīb, who returned to court shortly afterwards. Whether or not the anecdote is reliable, 'Arīb seems to have enjoyed less popularity during the reign of al-Mu'tașim and al-Wāthiq. ${ }^{18}$ However, when she died in about 890, she was highly respected and vastly wealthy. Her songs were collected and her biography was recorded. ${ }^{19}$ Unfortunately, those works have not survived and are only known by their titles.

During the time when 'Arìb enjoyed less popularity, she was outstripped by a rival who was about 20 years her junior. Shāriya was born in about 815 in al-Bașra, the illegitimate daughter of a Qurashī - as asserted by the woman who sold her and claimed to be her mother. The 'Abbāsid prince Ibrāhīm ibn al-Mahdī purchased the girl; he was one of the most famous bonvivants of his time and even counter-caliph for a short time (during an ill-defined period between 817 and 819). Years later, when Shāriya's alleged mother saw a prospect of coming into huge wealth, she wanted her back; she suddenly recalled the genealogy of the now famous girl, and claimed that Shāriya was freeborn. However, Ibrāhīm, a cunning jurist, managed to outwit her and keep Shāriya with him. Subsequently, Shāriya was manumitted during the reign of al-Mu'tașim or al-Wāthiq and had her glory days during the al-Wāthiq's caliphate between 842 and 847 . These however, ended when 'Arīb's popularity increased again during the time of alMutawakkil. Shāriya died in about 870 C.E. ${ }^{20}$

\section{The singing contest of Sāmarrā':}

It was probably during the reign of al-Mutawakkil, between 847 and 861, that Sāmarrā' witnessed a noteworthy event:21

“One day we sat together at Abū 'Isā ibn al-Mutawakkil's, who had invited us for a morning drink (șabūḥ). With me were also Ja'far ibn al-Ma'mūn, Sulaymān

17 Agh 18, 187. Al-Heitty, Poetess, 82, reads this as a manifestation of her pro-Barmakid attitude. However, I cannot see the coherence; it seems to me rather an attitude towards the family of al-Ma'mūn.

18 Stigelbauer, Sängerinnen 28 and 45, follows Agh 18, 187 saying that this aversion was based on the aforementioned conspiracy and her quarrels with al-Wāthiq (Agh 18, 186). Anyway, the caliph could also have simply preferred modernist singers, since he favored this style (FARMER, History, 148).

19 Agh 18, 176.

20 Stigelbauer, Sängerinnen 39ff, Eckhard Neubauer, Shāriya, in: EI², vol. 9 (1995), $350 \mathrm{f}$.

21 Agh 13, 29. 
ibn Wahb and Ibrāhīm ibn al-Mudabbir, furthermore 'Arīb and Shāriya and their singing-girls. We were all filled with joy, when Bid'a, 'Arīb's slave-girl, sang:

O criticizing woman, you increase your stupid blame, blaming me not for real fault or shame.

This song was by 'Arīb. Then 'Irfān sang:

And if my heart wants my beloved to separate, there are two advocates pleading her cause deep in my heart: her braids.

This song was by Shāriya."

At that time, the refined and well-bred people (ahl al-zarf wal-muta'ānūn) were divided into two communities (daffayn) - one supported 'Arīb ('Arībiyya) and the other backed Shāriya (Shärawiyya). Each party (hizb) favored the singer whom they admired (ta'așsaba, today also: to be a fan, devotee) in terms of applause (istiḥsān), țarab (see below), and improvisation (iqtirāhn). 'Arīb and Shāriya did not perform themselves: each singing-girl sang her mistresses' songs, none of them outperforming the other. Finally, Shāriya's girl 'Irfān sang:

Who, by my father, visited me in my dream ${ }^{22}$ at night, came close to me, averting yet his eyes at the sight?

She did well and received the desired applause. ${ }^{23}$

We continued to drink all together, when 'Arīb suddenly put down the cup and asked Shāriya: Tell me, my sister, who composed that melody? She answered: I did. I composed the song when my master, Ibrāhīm ibn al-Mahdī, was still alive. At that time I performed it in his presence. It won his acclaim, and he presented it to Ishāa and others, and they applauded as well.

Arīb did not reply, then she asked Abū 'Isā: By my father, Mylord, I would like you to send for 'Ath' 'ath and ask him to come here to me. ${ }^{24} \mathrm{Abu}$ 'Isā did as she had asked. 'Ath'ath came and sat down. When he had made himself comfortable, drank and sang, 'Arīb adressed him: Abū Dalīja, do you remember the song by Zu-

22 Manām obviously alludes to the motif of the beloved's dream figure. Of course one could also translate „bedroom“. The verse is quoted out of context.

23 Fa-ahssanat $m \bar{a}$ shä'at. I want to express the double meaning of ahsana.

24 Agh 13, 28 tells us that he was a black catamite who was later trained as a singer and poet. He had the kunya Abū Dalīja. BencheıkH, Musiciens, 130 mentions him as a disciple of Ibrāhīm ibn al-Mahdī. 
bayr ibn Daḥmāñ²5, which he performed in my house when you were there, and which he taught you at my request? So he recited (the verse she was talking about):

A virgin, can she ever forget the man who took her innocence?26 Nay!

By God! I swear, I still remember it as if we'd parted only yesterday!

And 'Arīb asked him: Sing it! So he started and sang exactly the melody which Shāriya('s girl) had performed before, until he had echoed it completely. 'Arīb burst into laughter and told her girls: Rehearse that in the right way, and then let's abolish the lie ( $d a^{\prime}$ ūna $\min$ al-bățil)! They started singing the old song, Bid'a and some of 'Arīb's girls, and Shāriya was abashed and bowed her head in shame, since her defeat was obvious. So she had not gained anything on this day, neither she herself, nor her singing-girls, nor any of her fans ( $\mathrm{min}$ muta'așșibīhā)."

Sāmarrā's upper class was split into two communities of devotees. This is illustrated in the frame of a matinée hosted by the high nobility ('Abbāsid princes, but also 'Arīb's friend - and maybe lover - Ibrāhīm ibn al-Mudabbir, an homme de lettres from Khurāsān's aristocracy). The terminology is striking: 'Arībiyya resp. Shärawiyya. This grammatical pattern refers to the adherents of a master or a (theological) concept, usually within a religious context. ${ }^{27}$ (The Latin fanaticus, later "Fan" derives from religious vocabulary as well). The notions hizb and ta'așșaba resp. muta'așșib also show a strong emotional moment. Etymologically, ta'așșaba is related to 'așabiyya, which means "clannishness" or "tribal cohesiveness".

'Arīb was able to convict her rival of plagiarism and, as such, managed to win the competition. The text does not talk about musical schools. Anyway, we learn that "... People were divided into two parties: some preferred Shāriya, others 'Arīb. The adherents of one party did not use to visit those of the other one, nor were they friends with each other." 28

25 BENCHEIKH, Musiciens, 130 assigns him to the school of Ishāa al-Mawșilī.

26 According to Georg Wilhelm Friedrich FreytAg, Lexicon Arabico-Latinum ex opere suo maiore in usum tironum excerptum, 1837, vol. 3, 125, Abu 'udhrihā means the man who deflowered a woman.

27 Ash'ariyya, "Dahrīya”: Josef van Ess, Theologie und Gesellschaft im 2. und 3. Jahrhundert Hidschra, 6 vols, vol. 4, de Gruyter: Berlin and New York 1997, 451-455 provided a brief discussion of the latter notion claiming it was an umbrella concept rather than a clearly defined school.

$28 \operatorname{Agh} 14,109$. 
That the devotees of the 'Aribiyya and the Shärawiyya did not visit each other is much more than one could say about the adherents of theological or even religious parties. Further:29

“Abū l-Ṣaqr Isma'īl was an 'Arībist ( kāna ... 'Arībiyyan). One Friday 'Alī ibn alHusayn invited him, when 'Arīb with her slave-girls was his guest. Shāriya gained knowledge of this. One or two days later, she sent her own singing-girls to 'Alì ibn al-Husayn and ordered one of them - I don’t remember if it was Mihrajān or Mutrib or Qamriyya - to sing:

Don't you return (to her), after she's gone!

But look, how I compose a song!"

STIGELBAUER, who usually translates reliably, reads only the first hemistich. This has led him to the wrong conclusion, namely, that Shāriya would forbid her disloyal fan to visit her again, because he dared to listen to 'Arīb. ${ }^{30}$ This interpretation fails to capture the competitive character of the anecdote: In fact, Shāriya intends to convince 'Alì (by showing her own talent as a songwriter) that she can do better than 'Arìb. As in the anecdote of the singing contest, there is no evidence that Shāriya would justify her supremacy by traditio. The rivalry seems to have persisted longer: "Shāriya started to play the lute only during the reign of al-Mutawakkil, in the context of the controversy between her and 'Arìb. 'Arīb wanted her to stop it, but Shāriya, nonetheless, continued."31

The Kitāb al-Aghāni tells us of manifold discussions on the question of who the best singer of a given period was. Sometimes, a compromise was found - that 'Arīb was the best and most creative composer - she wrote between 1,000 and 1,125 songs ${ }^{32}$ - while Shāriya and Farīda had the most beautiful voices, and $\mathrm{Mu}$ tayyam was brilliant in her technique. 33 'Arīb excelled in many ways, but there were also critics. Specifically, she was accused of having plagiarized herself (by using the same melody for different songs) and of having composed many rather worthless pieces: "Abū l-'Abbās ibn Ḥamdūn said to me, during a discussion about 'Arīb's songs, that many of them were not perfect, since she had produced lots of inferior songs, and that some of them were of modest quality. I replied: Who knows among the singers of the 'Abbāsid (caliphs and princes) one whose entire oeuvre would be perfect? Then I attempted to list all her good songs and reached a total of about 100.” [some examples followed, A.I.]

29 Ibid.

30 STIGELBAUER, Sängerinnen, 72.

31 Agh 14, 107. The narrator is Ibn al-Mu'tazz.

32 Agh 18, 176.

33 Agh 3, 177. 
"Herein we agreed, and finally he said: There was no woman after 'Arīb ( mā khalafat [...] mra'a mithluhā), who would have been able to hold a candle to her in the field of singing (ghinā'), recital (riwāya) or composing (șan'a). And I answered: And not a large number of men either!”34

'Arīb's biography specifically emphasized that she was unequalled since the time of the great Umayyad singing-girls. ${ }^{35}$ Here she is explicitly regarded as equal to her male colleagues. Nevertheless, there was pigeonholing as well. Some held the opinion that a good teacher necessarily made the better singer:

"Ibrāhīm ibn al-Mahdī bought Shāriya and she learned from him everything he knew about singing and even more. Some, herefore, prefer her to 'Arīb. They advance the argument that Ibrāhīm taught and trained her to perform with perfection and taught her his knowlegde (ma'rifa). The situation is different with 'Arīb, because al-Murādīi ${ }^{36}$ could not compete with Ibrāhīm regarding matters of knowlegde ..."37

The relation between teacher and disciple seems to be interpreted as a kind of genealogical one. Does this text provide the missing reference to traditio? Indeed we can assume that Shāriya was shaped musically by Ibrāhīm ibn al-Mahdī. Although she had been introduced to music by her alleged mother - who therefore seems to have been a singer as well - Ibrāhīm soon took over her training. He was famous for his beautiful voice and had a preference for the Persian style of music. Although improvisation was a feature of both the classical Arabic and modernist Persian style, the latter tended to adorn songs excessively. The classicists disapproved of this self-display of the singer, which in their eyes distorted the songs (hence, the singers 'Allūya and Mukhāriq were told that their music needed "bleeding"). ${ }^{38}$ Consequently, the point of difference is not so much composition, but performance. Specifically, although the passage between both was fluid: one should keep in mind, that musical notation at this time was usually just an aidemémoire. ${ }^{39}$ In my opinion, it is not correct to call the modernists "romantics." 40

$34 \operatorname{Agh} 18,190$, the narrator is Ğaḥza.

35 See Agh 18, 175 as well.

36 Stigelbauer, Sängerinnen, 21, suggests that this could be an error for al-Marākibī ('Arīb's first master).

37 Agh 14, 105.

38 Sic FARMER, History, 148 in a metaphorical sense referring to phlebotomy.

39 See Eckard NEUBAUER, Musiker am Hof der frühen 'Abbasiden (sic), Frankfurt am Main 1965, $34 \mathrm{f}$.

40 Frequently used by those following FARMER, History, 148. Improvisation, defined by the simultaneity of musical creation and performance (H. LindLAR, Improvisation, in: Marc HoNEGGER and Günther MASSENKEIL, Das grosse Lexikon der Musik in acht Bänden, Herder: Freiburg, Basel, Wien 1987, vol. 4, 159-161) is a common feature of Arab, Turkish, and Persian music 
'Arīb's case is not comparably obvious, although she is usually associated with the classical Arabic school. ${ }^{41}$ However, we find her in contact with most of the famous singers of her time, and indeed, showing a slight preference for those of the classical Arabic school, such as Ishāq al-Mawșilī (d. ca. 850), one of the most important singers of his time and an exponent of the classical tradition. However, there is no evidence that 'Arīb used to sing only in the classical Arabic style. A singing-girl, according to Risālat al-qiyān, had a repertoire of about 4,000 songs. ${ }^{42}$ We should assume that the girls mastered both styles well, even though they personally might have preferred one of them. Thus, Shāriya said that "her" song won the acclaim of Ishāq al-Mawșili, 43 an exponent of the opposing school, and similarly, 'Arīb's talent was examined and approved by Ibrāhīm ibn alMahdī. ${ }^{44}$ The song plagiarized by Shāriya was originally composed by an exponent of the classical style, Zubayr, who had taught it to 'Ath'ath, a disciple of the opposing modernist Ibrāhīm ibn al-Mahdī. ${ }^{45}$ Finally, not even the text on Shāriya's training provided evidence that she was taught only the modernist Persian style.

Neither Ishāa nor Ibrāhīm was mentioned as a reference model in the singing contest of Sāmarrā', nor did the musical traditio play a decisive role. ${ }^{46}$ Quite the contrary, Shāriya asserted that her song had delighted both of them, no matter which school they adhered to. When 'Arīb unveiled the deceit, there were no differences in the melody, although the real composer Zubayr belonged to the opposing traditio. This is remarkable since the modernists were blamed for corrupting the songs, so that one never heard them the same way they were

until now. However, it is not a characteristic of European romantic music. On the contrary, early and baroque music, like Arab music in our context, was not fully notated and left much space for improvisation. Famous virtuosi were nearly on equal terms with the composer, since the work was not complete unless performed. Romantic music, by contrast, tends to abolish improvisation by stressing the importance of notation ("Werkfixierung". See S. KunZE, Romantik, ibid., vol. 7, 114-119). Romantic music is further characterized by an increasing distinction between performer and composer, including the superiority of the latter. However, Ibrāhim believed the opposite: When blamed that his redundant improvisations corrupted the songs, he answered, that he was a king and son of kings, and thus, he sang as he liked (FARMER, History, 148).

41 As does Stigelbauer (Sängerinnen, 46) following FARMER, History, 148. Likewise BENCHEIKH, Musiciens, $146 \mathrm{f}$.

$42 \S 53$ according to the edition by BEESTON (Epistle, 21 of the Arabic text, 35 of the English translation).

43 Agh 13, 29.

$44 \operatorname{Agh} 18,181$.

45 BENCHEIKH, Musiciens, 130.

46 Ibrāhīm died probably about ten years before (d. 839), Isḥāq (d. ca. 850). 
composed. ${ }^{47}$ Even the fan communities ('arībì and shārawī) obviously referred to the person of the singer herself (while there were no comparable references of ibrāhìmī or ishạāi). Both women had achieved iconic status. They were idols of their time. 48

In this sense, female singers do not just continue a competition between two elder (male) stars nor does the narrator himself interprete the situation in this way. The singing contest of Sāmarrā' is not about two musical traditions, but about the rivalry between 'Arīb and Shāriya. The singers are the protagonists - not traditio. However, if it is not about tradition, what is the story talking about?

\section{Cultures of competition}

Singing, says al-Jāhịiz, ${ }^{49}$ is nothing but poetry with melody. Indeed poetry and music are closely connected. Most singers wrote at least some of their texts themselves, so it could be useful to regard music and poetry as parts of the same intellectual milieu rather than as separate components. Ibn al-Mu'tazz, author of the Kitāb al-Badī`, wrote down the biographies of the great singing-girls as well. Literary badī', as well as the Persian musical school, claim to be "modern" (badī') innovation) and to surpass tradition. ${ }^{50}$ However, this idea (of surpassing especially prior models) is not a characteristic of the modernist school. It refers less to a competition between schools, but is a phenomenon that can be found throughout the culture of the 9th century. It is found within the so-called schools as well as between them.

Poetry and singing contests were extremely popular in 9th century courtly life. Even among theologians we can find famous permanent rivalries, such as that of Ibn ar-Rēwandīin and al-Khayyāt. Educated slave-girls, who took part in contests even found their way into the Arabian Nights like Tawaddud, who com-

47 FARMER, History, 148.

48 One should keep in mind the original meaning of "icon" and "idol" in the religious sense. Our modern concept of the "star" as a secular cult figure is derived from religious sphere. Star cult - even if it is one avant la lettre - phenomenologically resembles religious cults in many respects, especially regarding the strong emotionality.

$49 \S 31$ according to BEESTON, Epistle, 11 (23f in the English translation).

50 See the comprehensive analysis by Stefan SPERL, Mannerism in Arabic Poetry. A Structural Analysis of Selected Texts, Cambridge 1989.

51 I follow the transcription of VAN Ess, op. cit., especially 295-349 (chapter on Ibn ar-Rēwandī). 
peted among others with the famous theologian al-Nazzām. ${ }^{52}$ Generally, from the beginning of the 9th century, we note a great interest in disputes, contests, and verbal controversies. During the first decades of the century, the naqa' id between Jarir and Farazdaq resp. al-Akhțal (dating to the 7th and early 8th century) were collected. This type of satirical feud was in fashion, and not only among male poets: The poetess Faḍl (d. ca. 870), for instance, was the heroine of several "poetry slams." AL-HeITTY ${ }^{53}$ quoted different verses that she composed extemporaneously, competing with other poets during a majlis. She also had an invective competition with another slave poetess: 54 Both accompanied by male supporters, the two poetesses were anything but squeamish in attacking each other in the way of Jarī and Farazdaq. 55

Regarding the context of music, the quarrel between Ishāq al-Mawșilī and Ibrāhīm ibn al-Mahdī is by no means the only one. So Ishāq's father, Ibrāhīm al-Mawșilì, competed with a colleague in the presence of Hārūn ar-Rashīd, who knew more songs than the other. Ishāa himself outstripped Ibrāhīm ibn al-Mahdī in his ability to charm sounds out of a completely off-tuned lute. He also competed against the singer Mukhāriq, both of them singing the same song, trying to outperform each other. ${ }^{56}$ Moreover, the singing-girls were by no means only objects of dispute, but also active competitors; in fact, a similar contest was related about Maḥbūba. ${ }^{57}$

Thus, Shāriya was not 'Arīb's only opponent. The enfant terrible of the 'Abbāsid court challenged an even more prominent rival: Caliph al-Wāthiq. We learn about the music enthusiast al-Wāthiq: 58 "Whenever al-Wāthiq had written a

52 The interpretation of this (vastly discussed) and similar stories that slave-girls in the context of intellectual contests were a parody or expression of disdain towards the other participant, is of course inadequate. It was falsified as early as in 1973 by Claudine GERRESCH, Un récit des Mille et Une nuits: Tawaddud, petite encyclopédie de l'Islam médiéval, in: Bulletin de l'Institut Fondamental de l'Afrique Noire, Serie B 35, 1 (1973), 57-175, p. 114. GERRESCH points out, that Tawaddud incorporates in an ideal way the extensive education of slave-girls (ibid., 115. The article provides also bibliografy including manuscripts). Further recent studies by Claude BREMOND and Bernard DARBord, Tawaddud et Teodor: les enjeux ludiques du savoir, in: Michelangelo Picone (ed.), L' enciclopedismo medievale, Longo: Ravenna 1994, 253-273. M.R. PARKER, The Story of a Story across the Cultures. The Case of the Doncella Teodor, London 1996.

53 Role of the Poetess, $235 \mathrm{ff}$.

54 Agh 21, 118 a certain al-Khansā', slave-girl of Hishām ibn Makfūf.

55 Translation by STigelBaUER, op. cit., 141f, for further "poetry slams" in general ibid. 33 and 70.

56 SAWA, Performance, $178 \mathrm{ff}$ for these and similar competitions.

57 Translated by StigelbaUER, Sängerinnen, 59 (from al-Mas'ūdī’s Kitāb murūj al-dhahab).

58 Agh 18, 186. 
melody (on a poem), 'Arīb would compose another melody on the same text, which surpassed his." This seems to be one of the reasons, why she was in his bad books - not to mention that she may have tried to kill him personally. ${ }^{59}$ His uninspired music, however, does not seem to have been the reason for the latter attempt.The competition between 'Arīb and Shāriya was not an isolated incident, to be understood in the context of another quarrel. Instead, poetical and musical contests were common courtesy. This takes us to the notion of aemulatio.

Over the past few years, the notion of aemulatio has been investigated by several scholars and is considered from different angles, usually in terms of art history and literary criticism regarding the European Renaissance or Byzantium. ${ }^{60}$ Although it is difficult to transfer European concepts to the Arab world, it makes sense in this case. Byzantium and classical antiquity were important reference models for the Arab world of the 9th century. Arab scholars regarded themselves as heirs of the ancient Greeks as did their Byzantine colleagues. Music was regarded as a part of the Greek heritage, and indeed, Arab music theory shares similar concepts with the latter (for instance regarding the maqāmāt). ${ }^{61}$ Al-Jāhiz stresses the close relation between music and poetry (and therefore, sensu lato, also with rhetoric), but also between music and psychology (see below). This refers to Graeco-Byzantine patterns as well, and indeed, al-Jāḥiz points out two non-Arabic and pre-Islamic types of influences on music:"62 "The Persians regarded singing as adab, the Rūm (Byzantines: as distinguished from Yūnān: ancient Greeks) as (a branch of) philosophy."

Reference points like these justify the act of seeking examples of aemulatio in Sāmarrā' as well. We do find them in official court poetry such as the Qașidas by al-Buhturī (820/1-897). As early as in 1989, Stefan SPERL dealt extensively with the panegyric on the basin of al-Mutawakkil, which surpassed all wonders of architecture, both of the ancient world and of nature. ${ }^{63}$ We should add that if the basin surpasses nature, this is to say that the creation of the caliph surpasses even that of God! In this case, we note primarily the concept of aemulatio veterum, which is to surpass prior models.

59 Agh 18, 187. But as said above, this caliph preferred the modernist style anyway.

60 Jan-Dirk MüLlER et. al., eds., Aemulatio. Kulturen des Wettstreits in Text und Bild (14501620), De Gruyter: Berlin 2011, and RHoвy / SCHIFFER, Imitatio.

61 Especially music theory, unlike singing as such, compare the frequent distinction between singing ('ilm al-ghinā') and music theory ('ilm al-mūsīqa) ), the latter being ascribed to the "Greek sciences.”

$62 \S 28$ according to the edition by BEESTON (Epistle, 10 of the Arabic text, 22f of the translation). 63 SPERL, Mannerism, 38 ff, dealing with Poem Nr. 915, to which Ibn al-Mu'tazz refers as a perfect example of $b a d i c$. 
'Arīb and Shāriya, however, were not official court poetesses. Yet, it is worth taking a look at their biographies as related by the Kitāb al-Aghānì: 'Arīb was compared repeatedly with the great singers of the past: 18,175 notes, that from the time of the great Umayyad singing-girls there was no one like her; 18, 190 claimes that no other singing-girl equalled her either: She survived comparisons with the singers of the past, and became a model herself. Likewise, we learn of how Shāriya $(14,105)$ had been taught by Ibrāhīm ibn al-Mahdī all he knew, and even more. Remarkably, Shāriya exceeded even her master - a noteworthy case of a woman who outshone a man.

A recent publication of a conference on aemulatio ${ }^{64}$ emphasized that the key elements in the aesthetics of early modern times (as the example of the rivalry between Michelangelo and Leonardo da Vinci shows) include outstripping models from the past and exceeding coeval rivals (aemulatio modernorum). In this light, we find several aemulative motifs in the text on the rivalry of Sāmarrā': Shāriya tried to win back her renegade admirer, 'Alī, and to convince him that she was the better musician. ${ }^{65}$ She staged her protest by sending her singing-girls to him and by delivering the message (i.e., "I'm the better one!") in the form of a song on the situation. In this way, she simultaneously proved the superiority she claimed, and the way in which 'Arīb made her rival look like a fool in the singing contest was remarkable as well. She did not simply say: "This is a plagiarism," instead, she turned her triumph into good publicity and showed remarkable stagecraft.

Then, what is the difference among plagiarism, imitatio, and aemulatio? Shāriya was deemed a plagiarizer not because she allowed her singing-girl to perform a melody created by another composer, but because she claimed that it was her own creation. ${ }^{66}$ Even in order to imitate a paragon, one has to name it or to make sure that the audience knows the work one refers to; the more so if one wants to surpass it (as aemulatio is defined). ${ }^{67}$ Thus, naming the paragon as well as surpassing it are the features of aemulatio.

64 MÜLLER et. al., Aemulatio.

65 Agh 14, 109.

66 It was not unusual for different melodies to be composed on the same text, as 'Arïb does in her competition with al-Wāthiq. Ișfahānī interprets this as aemulatio. Shāriya's case is different: She uses the melody of another singer, pretends that it was hers and that she had just changed the words. Even today we distinguish a new, maybe better musical version of a text from musical plagiarism (copy of a melody). SAWA already noted that plagiarism could lead to a defeat, Performance, 179.

67 See above. 
This distinction can be illustrated by another anecdote from 'Arīb's biography, which is constructed in a similar way. ${ }^{68}$ In that anecdote, 'Alī ibn Yahyā al-Munajjim related how 'Arīb once asked him about a meeting (majlis) in the caliph's palace. She wanted to know, who had been the singers and which song had been the best-liked (istahsana). He replied that it was a song by Bunān. ${ }^{69}$ 'Arīb wanted to hear the verses, and he recited them for her. Then she sent for Bunān, dined and had wine with him, and finally asked him to perform his song. As soon as he had finished his performance, 'Arīb composed another four-lined stanza in the same metre (more or less) spontaneously. According to other sources, she also changed the maqām (Tropos, mode) of the melody. Bunān was so impressed that he decided to adopt her new version. ${ }^{70}$

The story is constructed conspicuously similarly to that of the singing contest of Sāmarrā' - 'Arīb learns about a song, sends for the singer, and so on. However, there are differences that are detected. In this anecdote, the song is attributed to its real composer. 'Arīb by no means tried to make anybody believe that she composed the melody. She staged her version as a reply to - even as an improvement - of that song. Based on the most successful song of yesterday's majlis, she subsequently provoked a competition, which she could not hold in the presence of the ruler himself. She made sure that there was a witness to tell the caliph about her triumph. By first making Bunān sing his own version and then improvising a better one, she turned the encounter into a staged contest. Bunān finally admitted that her version surpassed his own (the most-liked song of yesterday's meeting). That fact that 'Arīb did it better symbolized real aemulatio.

That the singing contest of Sāmarrā' was interpreted as a continuation of another quarrel may be due to the fact that the protagonists were female. Anecdotes about slave-girls were often dominated by sexual aspects; thus, it was difficult to imagine that the singing contest was a competition between two (female) artists. ${ }^{71}$ Further, it seemed inconceivable that women could achieve such huge popularity - even less so because the 9th century is usually regarded as a period of increasing segregation of women from public space. ${ }^{72}$ The disappearance of noble

68 Arabic text quoted in AL-HeitTy, Poetess, $215 \mathrm{f}$.

69 Famous singer, coeval.

70 aL-HeitTy, Poetess, ibid.

71 Regarding the singing contest, however, this aspect is not relevant. Especially, 'Arīb was already beyond the age when a singing-girl would have passed as an object of erotic dreams.

72 This is briefly discussed in Susanne ENDERWITZ, Liebe als Beruf. Al-'Abbās ibn al-Ahnaf und das Gazal, Franz Steiner Verlag: Stuttgart and Beirut 1995, 93. Al-Washshā', Abū 1-Ṭayyib Muḥammad ibn Isḥāq ibn Yaḥyā, Kitāb al-muwashshā, ed. Rudolph E. BRÜNnow, Leiden 1886, 93, refers still to the conflict that a zarif preferred women of his own (noble) range, but this had become difficult, since these women were jealously guarded. Similarily ibid., 100. 
women from public life, however, created a void. Singing-girls benefited from this. Noble women continued to sing, but they could no longer perform in front of a male audience; sometimes, they were even forced to conceal their talent from their families. ${ }^{73}$ Since comparable moral demands were not expected of singinggirls, they temporarily occupied this void.

Hence, one should consider parallels between male and female singers, which are indeed striking. As has been noted by several studies, the ideal of an educated (male) singer is connected with the urban life-style of zarf (refined elegance) and also with the idea of the educated Kātib. ${ }^{74}$ Thus, many male singers claimed prestigious genealogies. No less a figure than Ibrāhīm al-Mawșilì, father of Ishāa, maintained a noble descent: It was only due to adverse circumstances that he had become a vagabond, the fault of a despotic Umayyad governor (i.e., an enemy of the now ruling dynasty). These types of legendary genealogies were also spread by female musicians: 'Arīb, Shāriya and Faḍl all claimed to be free born, even noble women, who had been sold into slavery unjustifiably. ${ }^{75}$ Especially in the context of the court, famous female singers behaved like the male zarif. They cooked and jested, met friends and patrons, performed music, and then competed with each other in their own houses, at a friend's or at court. Music was closely connected with urban life and its ideals. It seemed that male and female singers adapted their biographies to this ideal, as soon as they had attained a certain position. This included claiming noble descent and also an aemulative form of behavior.

In the singing contest 'Arīb and Shāriya de facto appear to be equal to their male companions ('Arīb also appeared as such in the anecdote with Bunān). They were invited into a patron's house, where they did not expose themselves, but celebrated with their friends leaving it to their slave-girls to entertain the circle. It seems that the most famous female singers of the 9th century succeeded in transgressing gender role-models and in participating in the cultural discourses of their time. One should, therefore, regard the two singers not so much as musicplaying-women, but rather as musicians, who happen to be women. At that time, musicians were - in a certain frame - public figures. Their contests were held in public in the same way as the singing competition of Sāmarrā's as staged rivalries.

73 Agh 14, 110.

74 This is a concept that has been exhaustively dealt with by ENDERWITZ, Liebe, 47-67, in the context with musicians and singing-girls: Eckhard NeUBAUER, Musiker, 46, STIGELBAUER, Sängerinnen, 73 ff, BencheikH, Musiciens, 130ff, Engel, Stellung, 276.

75 'Arīb was an alleged daughter of the Barmakid vizier Ja'far (Agh 18, 177ff). Shāriya claimed that she was from Quraysh (different versions, see for instance Agh 14, 105). Faḍl, too, claimed to be the legitimate daughter of a free man (Agh 21, 114). 


\section{Touchstones of aemulatio}

The criteria by which the success of aemulatio was determined in the courtly setting are named explicitly: ${ }^{76}$ applause (approval of the audience), tarab (the performance itself, including its impact on the audience), and improvisation (including technique).

\section{Istihssān - Approval}

The aspect of public approval is quite obvious in the narration about the singing contest of Sāmarrā'. The slave-girls took turns at singing their respective mistresses' songs, and none surpassed the other. Finally, 'Irfān performed the controversial song, and "she did well and attained the desired applause". ${ }^{77}$ At this point, Shāriya seemed to be the front-runner. When narrating the tall tale about the composition of the song, she claimed to have performed it in front of the most famous authorities of her youthful days and maintained that the song had met with their approval. ${ }^{78}$ In addition to claiming the applause of the present audience, she strengthened her position by invoking the approval of famous men of the past. When 'Arīb exposed the fraud, 'Arīb regained the approval of the audience.

\section{Tarab}

We cannot provide a detailed explanation of the complex concept of tarab here. ${ }^{79}$ On the one hand, it means simply performing music; but this is not what our singing contest is about, since 'Arīb and Shāriya do not themselves perform. However, as we learn from another anecdote quoted above, Shāriya's luteplaying had displeased 'Arīb - because it enabled the rival to surpass her own performance. On the other hand, tarab means the impact of music performance on the audience or the evoking of emotions through music. It is for this reason that al-Jāhị connected music with psychology 80 (Others attribute it to medicine or even magic). This is based on the idea - probably deriving from Greek models - that music has

76 In the story quoted above Agh 13, 29.

77 Ahsanat, for details see above.

78 Istahsana.

79 This will be done on another occasion. For a short discussion of the notion see ENGEL, Stellung, $133 \mathrm{f}$.

$80 \S 31$ according to BEESTON, Epistle, 12: “Wa kitāb al- 'arūd min kitāb al-mūsīqā, wa-huwa min kitāb hadd an-nufūs ...” He seems to refer to Greek concepts of "psychology”, maybe Aristotle's

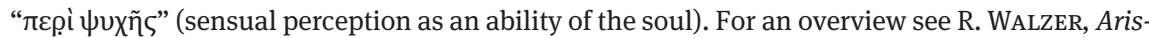
țūtạaliss, in: EI², vol. 1 (1960), p. 630-33. For music as a therapeutic see ENGEL, Stellung, 36-38. 
an influence on body and soul, which can be used therapeutically. Al-Jāḥiz related about Yazīd ibn 'Abd al-Malik:

"Yazīd used to listen (to his singing-girls Sallāma and Habbāba, my addition), and when specially moved (taraba) he would rend his garment and cry: I am transported! And Habbāba would reply: Please don’t be transported!; we need you!"81

It is a topos of tarab that the audience is so transported by emotion that theywould rend their garments in response to one's performance. In our singing contest, this is alluded to only marginally in talking about the "fans" of the two singers (ta'așsaba). Their strong emotional commitment refers to the notion of țarab.

\section{Iqtirāḥ - Improvisation}

Vocal improvisation is still an important feature of Arabic music today. The singer can display his or her technique, creativity, and beauty of voice. During the 9th century, improvisation carried a great weight, especially in the modernist Persian style. In the classical Arabic tradition, music theory defines which notes to stress by improvisation, too. ${ }^{82}$ Further, improvisation includes even impromptu composition of songs, as we have demonstrated in our discussion about the competition between 'Arīb and al-Wāthiq or Bunān ${ }^{83}$ - it is a key element of the great singing competitions. Thus it was by no means just a feature of Persian style, even if the latter gave the singer more space for it.

As demonstrated in discussing the notion of "romanticism" above, improvisation gave the singer a position comparably important to that of the composer. Since the work was not fully notated, it was not complete unless performed. Thus, the singing-girl was not "l'umile ancella del genio creator," 84 but in special cases, was considered at least equal to the composer, and rather comparable to the great castrati (Senesino, Farinelli) and divas of the baroque era. The passage betweeen improvisation and composition was fluent anyway, and indeed many singinggirls were also composers. Therefore, we have to relativize STIGELBAUER's argument that the singing-girls did not contribute much to musical developments, rather, they were reproducing artists who were interested primarily in hard

$81 \S 29$ according to BEESTON, Epistle, 10f. Translation ibid., 23, my additions.

82 SAWA, Performance deals extensively with melodic ornaments, 91-105.

83 Precomposed songs and improvisation discussed by SAwA, Performance, 138-144.

84 F. CiLEA's Adriana Lecouvreur (1902, act one, sc. three): The aria “Io (i.e. the singer/actress) son l'umile ancella del genio creator" is the credo of a singer of the late romantic era. 
cash. ${ }^{85}$ Without knowledge of music theory, it was simply impossible to perform. In our singing contest, Shāriya seems to have adhered closely to the original melody ("So he started and sang exactly the melody, which Shāriya's girl had performed before"). This is the more remarkable since it means that the song had been performed by the girl in the classicist way (The modernists were accused of changing the songs out of recognition). Had Shāriya performed it personally, she probably would have at least improvised in a witty way and thus have contributed to the song. However, since she did not reveal the name of the real composer, nor improved on the song, she was just a cunning plagiarizer and, in the end, failed to present the key element of aemulatio: Doing it better.

\section{Traditio vel aemulatio?}

There is no evidence to suggest that the singing contest of Sāmarrā' deals with traditio. On the contrary, it is obvious that female singers are perceived as autonomous idols themselves. Music is mainly performance, and the significance of improvisation allows the singer, male or female, to assume a key position. Thus, 'Arīb and Shāriya stage their rivalry and even their biographies according to current patterns of zarf. But the singing contest is not only about stereotypes. Arab Music of the 9 th century, regardless of the school, is further characterized by the aemulative event, especially in the form of competition and contest. The aemulative character and the great weight of improvisation (and impromptu composition) also refer to an increasing relevance of the individual: It is the individual person who challenges the famous masters of the past as well as his or her contemporaries.

\section{Bibliography}

\section{Primary sources:}

Beeston, A.F. L., The Epistle on Singing-girls of Jähiž. Edited with Translation and Commentary by A.F.L. Beeston, Guildford 1980.

al-Ișfahānī, Abū l-Faraj, Kitāb al-aghānī, Dār al-Fikr, 21 parts and Index in 9 vols., equivalent to the edition Kairo 1322/1905-5.

al-Washshā', Abū l-Ṭayyib Muḥammad ibn Isḥāq ibn Yaḥyā, Kitāb al-muwashshā, ed. by BRüNNow, Rudolph E., Leiden 1886.

85 Op. cit., 119. Similar misinterpretations were frequent in the cases of Clara Schumann or Fanny Mendelssohn. 


\section{Secondary sources:}

BAUER, Barbara, Aemulatio, in: Ueding, Gert, ed., Historisches Wörterbuch der Rhetorik vol. 1 (1992), 141-188.

BENCHEIKH, Jamel Eddine, Les musiciens et la poésie. Les écoles d'Isḥāq al-Mawșilī (m. 225 H) et d' Ibrāhïm ibn al-Mahdī (m. 224 H), in: Arabica 22 (1979), fasc. 2, 114-152.

BREMOND, Claude and DARBord, Bernard, Tawaddud et Teodor: les enjeux ludiques du savoir, in: Picone, Michelangelo, ed., L' enciclopedismo medievale (Atti del convegno L' enciclopedismo medievale, San Gimignano 8-10. Ottobre 1992), Longo: Ravenna 1994, 253-273.

ENDERWITZ, Susanne, Liebe als Beruf. Al-'Abbās ibn al-Ahnaf und das Gazal (Beiruter Texte und Studien vol. 55), Franz Steiner Verlag: Stuttgart, Beirut 1995.

ENGEL, Hans, Die Stellung des Musikers im arabisch-islamischen Raum, Bonn 1987.

VAN Ess, Josef, Theologie und Gesellschaft im 2. und 3. Jahrhundert Hidschra, 6 vol.s, vol. 4 de Gruyter: Berlin, New York 1997.

Farmer, Henry G., A History of Arabian Music to the XIII. Century, London 1929.

- The Minstrels of the Golden Age of Islam, in: Islamic Culture XVII (1943), 273-281 and XVIII (1944), 53-61.

FREYTAG, Georg Wilhelm Friedrich, Lexicon Arabico-Latinum ex opere suo maiore in usum tironum excerptum, 1837.

GERRESCH, Claudine, Un récit des Mille et Une nuits: Tawaddud, petite encyclopédie de l'Islam médiéval, in: Bulletin de l'Institut Fondamental de l'Afrique Noire, Serie B 35, 1 (1973), 57-175.

AL-Heitty, Abdul Kareem, The Role of the Poetess at the Abbasid Court (132-247 / 750-861). A Critical Study of the Contribution to Literature of Free Women and Slave-girls under the Early Abbāsid (sic) Caliphate, their Biographies and Surviving Works, Beirut 2005.

Hickmann, Hans and Stander, Wilhelm, Orientalische Musik, in: SPuler, B., ed., Handbuch der Orientalistik 1. Abteilung, Ergänzungsband 4, Leiden, Köln 1970, 1-134.

Honeg Ger, Marc and MASSENKeIL, Günther, Das grosse Lexikon der Musik in acht Bänden, Herder: Freiburg, Basel, Wien 1987.

KRAEMER, Joel, Humanism in the Renaissance of Islam, Leiden 1992.

v. KREMER, Alfred, Kulturgeschichte des Orients unter den Chalifen, Wien 1877.

MülLeR, Jan-Dirk, et. al., eds., Aemulatio. Kulturen des Wettstreits in Text und Bild (1450-1620), De Gruyter: Berlin 2011.

Neubauer, Eckard, Musiker am Hof der frühen 'Abbasiden (sic), Frankfurt am Main 1965.

- Shāriya, in: $E l^{2}$, vol. 9 (1995), $350 \mathrm{f}$.

Neumann, F., Tradition, in: Ueding, Gert, ed., Historisches Wörterbuch der Rhetorik vol. 9 , Tübingen 2009, 732-41.

PARKER, M.R., The Story of a Story across the Cultures. The Case of the Doncella Teodor, London 1996.

Pellat, Charles, Kayna, in: El² vol. 4 (1978), 820-824.

Rнову, Andreas and Schiffer, Elisabeth, eds., Imitatio - Aemulatio - Variatio. Akten des internationalen wissenschaftlichen Symposions zur byzantinischen Sprache und Literatur (Wien 22.-25. Oktober 2008), Verlag der österreichischen Akademie der Wissenschaften: Wien 2010.

SAWA, George, Music Performance Practice in the Early Abbasid Era, Ottawa 2004 ('Toronto, Ontario 1989).

SHILOAH, Amnon, Music in the World of Islam. A Socio-Cultural Study, Aldershot 1995.

- $\quad$ The Theory of Music in Arabic Writings, 2 vol.s, Henle: München 1979, 2003. 
SPERL, Stefan, Mannerism in Arabic Poetry. A Structural Analysis of Selected Texts, Cambridge 1989.

Stigelbauer, Michael, Die Sängerinnen am Abbasidenhof um die Zeit des Kalifen al-Mutawakkil. Nach dem Kitāb al-Aġānī des Abu l-Farağ al-Ișbahānī (sic) und anderen Quellen dargestellt, Wien 1975.

WALZER, R., Arisțūțālīs, in: El², vol. 1 (1960), 630-33. 